\title{
Beauvoir on Women's Complicity in Their Own Unfreedom
}

\author{
CHARLOTTE KNOWLES (D)
}

In The Second Sex, Simone de Beauvoir argues that women are often complicit in reinforcing their own unfreedom. But why women become complicit remains an open question. The aim of this article is to offer a systematic analysis of complicity by focusing on the Heideggerian strands of Beauvoir's account. I begin by evaluating Susan James's interpretation of complicity qua republican freedom, which emphasizes the dependent situation of women as the primary cause of their complicity. I argue that James's analysis is compelling as far as it goes, but that it implies complicity is the inevitable outcome of women's current existence and fails to adequately account for Beauvoir's claim that women actively embrace their own unfreedom. I then draw out the Heideggerian strands of Beauvoir's analysis, demonstrating how this enables us to systematize Beauvoir's account of women's oppressive situation with her claims regarding the active role women can play in reinforcing their own unfreedom. I argue that this approach preserves the strengths of the republican interpretation, but provides a better account of cases where complicity may not be inevitable and yet some women still act to reinforce rather than resist their own unfreedom.

Men have been punished summarily, forced out of their jobs when all they did was touch someone's knee or try to steal a kiss. - Catherine Deneuve, open letter in Le Monde, January 2018

"There were a couple of men that were a bit gropey [working in the UK parliament in the 1990s]. But do you know what? I was flattered." - Petronella Wyatt on BBC Radio 4's Today Programme, November 2017

In late 2017 the \#MeToo campaign drew public attention to the continued prevalence of sexual harassment in contemporary society. The campaign was seen by many 
as a positive move toward combating gender oppression and ushering in a more equal age where women no longer have to fear harassment in the workplace or on the streets. But the backlash soon began in earnest. Among the critics of \#MeToo were a number of prominent women, including the French actor Catherine Deneuve and the British journalist Petronella Wyatt, who both implied that \#MeToo confused courtship with harassment. Deneuve denounced \#MeToo campaigners as "puritanical" and branded the movement a "witch hunt" (Deneuve 2018b); Wyatt claimed that "a lot of abuse or sexual harassment is a breach of good manners," and that this is in part women's fault because "women have waived their right to gallantry by saying we're the same as men" (Wyatt 2017). Criticism was made of Deneuve and Wyatt on the basis that their comments denied the reality and harms of sexual harassment and the role it plays in the subordination and oppression of women. In response, Deneuve invoked Simone de Beauvoir in an attempt to present her views as consistent with the legacy of a Beauvoirean feminism of freedom (Deneuve 2018a; Deneuve 2018b). What Deneuve overlooked, however, is that Beauvoir is also a central theorist of female complicity, and that this analysis provides an alternative way to interpret Deneuve's and Wyatt's responses to the \#MeToo campaign.

Complicity describes the way in which an agent can help to reinforce or perpetuate their own unfreedom. ${ }^{1}$ The classic case of complicity is the rarefied example of the voluntary slave, who chooses to adopt a way of life that alienates them from their own freedom. But for Beauvoir, complicity is a commonplace feature of female existence (Beauvoir 1949/2011, 757). The Second Sex offers various compelling examples of the different ways in which women can be complicit in reinforcing their own unfreedom, including by embracing and defending their position as sexual objects (667). Beauvoir interlaces materialist, existentialist, and phenomenological analyses to create a rich picture of the unfree situation of women in society, but why women become complicit in their own unfreedom remains an open question. ${ }^{2}$ The aim of this article is to offer a systematic analysis of agents' complicity in their own unfreedom by focusing on the Heideggerian strands of Beauvoir's account. I begin by examining Beauvoir's understanding of complicity in The Second Sex, before evaluating Susan James's interpretation of complicity in terms of seventeenth-century accounts of slavery and republican freedom, which emphasizes the dependent situation of women as the primary cause of their complicity. James's analysis is compelling as far as it goes, but I argue that it makes complicity seem like the inevitable outcome of female existence and fails to adequately take account of Beauvoir's claim that women actively embrace their own unfreedom. To overcome these objections, I propose an alternative interpretation of complicity by drawing out the Heideggerian strands of Beauvoir's analysis. I demonstrate how this approach enables us to systematize the active role agents play in reinforcing their own unfreedom with the role situation plays in drawing women into complicity, thus giving equal weight to the coercive social setting and to the active role of the agent in its explanation of complicity. I argue that this approach preserves the strengths of the republican interpretation, but is better able to account for instances where complicity may not be inevitable-such as in the case 
of privileged, wealthy, women like Deneuve and Wyatt-and yet agents still act to reinforce rather than resist their own unfreedom.

\section{Complicity in The Second SeX}

Beauvoir begins The Second Sex with an impassioned discussion of the way in which women have been, and continue to be, unfree, a characterization that still has contemporary resonance:

Woman has always been, if not man's slave, at least his vassal; the two sexes have never divided the world up equally; and still today, even though her condition is changing woman is heavily handicapped... even when her rights are recognized abstractly, long-standing habit keeps them from being concretely manifested. Economically, men and women almost form two castes; all things being equal, the former have better jobs, higher wages, and greater chances to succeed than their new female competitors; they occupy more places in industry, in politics, and so forth, and they hold the most important positions. (Beauvoir 1949/2011, 9)

Here Beauvoir offers a material account of women's unfreedom, explained in terms of their unequal position in society and their subordination to and dependence on men. ${ }^{3}$ This idea finds its philosophical articulation in the notion of woman as "Other." ${ }^{4}$ Not only are women unfree in a material sense, having fewer resources and fewer opportunities than men, but at a more universal level women are unfree because they are conceived of as the "Other." This existential Otherness, Beauvoir argues, defines the general situation of woman and helps to explain her material and social unfreedom. To be Other in this existential sense means to be the passive object to man's active subject: "she determines and differentiates herself in relation to man, and he does not in relation to her; she is the inessential in front of the essential. He is the subject, he is the absolute. She is the Other" (6). Beauvoir is clear that man casts woman into this position, but she also acknowledges that "[t]he man who sets the woman up as an Other will thus find in her a deep complicity" (10). That is to say, woman does not reject her position as the Other, as man's passive and dependent counterpart, rather she accepts and even embraces this position, despite the fact that it is one in which her "humanity is effectively denied" and her freedom is "effective[ly] suppress[ed]" (Kruks 1987, 115). How then does Beauvoir explain this perplexing state of affairs? Why do women embrace rather than resist their own unfreedom?

\section{The Situation of Woman, the Benefits of Complicity, and James's Republican INTERPRETATION}

A central aspect in Beauvoir's explanation of female complicity is woman's situation. For Beauvoir, an agent's "situation" does not just mean the brute facts of her 
environment, her body, or her life, although it does include these. Rather, our situation "is our grasp on the world and a sketch of our projects" (Beauvoir 1949/2011, 44). For Beauvoir we are both in a situation and (our bodies) are a situation. That is to say, with regard to complicity, woman's situation not only describes how women are unfree in society from an external point of view: being subordinate to and dependent upon men, having fewer resources and opportunities than they do. Woman's situation also speaks to the way women experience this unfreedom, how it comes to shape how women view themselves, their capabilities, and the opportunities that are open to them. Beauvoir's account of situation gives a constitutively relational picture of human existence. ${ }^{5}$ Moreover, two people may be in the same physical environment, but occupy very different situations. For example, a woman walking down a street may feel threatened, or find herself constantly having to dodge out of other people's way, whereas a man walking down the same street may stride confidently along the pavement without having any of these experiences. Our situation describes the particular way in which we are opened onto the world and "encompasses both the objective and subjective aspects of experience" (Moi 1999, 68).

In her interpretation, Susan James implies that situation is the key determinant of women's complicity, although she develops this analysis through the lens of seventeenth-century accounts of slavery and republican freedom. ${ }^{6}$ James argues that for Beauvoir, as for the republican theorist, "freedom can only exist between equals who are not bound by relations of dependence" (James 2003, 165). Since woman's situation is one of extreme dependence on man, James argues Beauvoir conceives of woman as a slave in a sense "continuous with one to be found in seventeenth-century accounts of social hierarchy" (165). In this republican sense, to be a slave is not necessarily to lack political freedom, but rather to be "socially and psychically unfree" because one exists in a situation of dependence (164). ${ }^{7}$ On this reading, "complicity is not a matter of choice" (160). Rather, women's situation of dependence and subordination distorts their psychology, ${ }^{8}$ leading women to become complicit in ways of life they would not otherwise choose.

Beauvoir undeniably sees women's material situation of dependence and subordination as central to her explanation of female complicity. However, in addition to her emphasis on situation, Beauvoir also suggests that there may be certain benefits to being complicit:

Refusing to be the Other, refusing complicity with man, would mean renouncing all the advantages an alliance with the superior caste confers on them [women]. Lord-man will materially protect liege-woman and will be in charge of justifying her existence: along with the economic risk, she avoids the metaphysical risk of a freedom that must invent its goals without help. (Beauvoir 1949/2011, 10)

James notes the material benefits of complicity, but downplays what Beauvoir says regarding the metaphysical benefits, ultimately giving primacy to women's situation of subordination and dependence in her interpretation of Beauvoir's analysis. 


\section{The Limitations of the RePUblican InTERPRETATION}

As far as it goes, James's interpretation of complicity is compelling. It enables us to see why women may accept their subordinate position and not struggle against their own unfreedom, since their dependent situation forms them into compliant subjects. As Beauvoir herself states, and as James emphasizes, woman's "whole education conspires to bar her from paths of revolt and adventure" (Beauvoir 1949/2011, 757). But by rooting the cause of woman's complicity primarily in factors "external" to her, that is, explaining complicity in terms of the way woman's situation leads her to accept ways of life she would not otherwise choose, one fails to do justice to Beauvoir's account of active complicity. ${ }^{9}$

It is not simply that women accept their position as the Other because they have no other option. Indeed, if they did this would not, strictly speaking, be a case of complicity. Complicity implies the ability to do otherwise. I cannot be complicit in something I cannot avoid doing. ${ }^{10}$ The unfreedom of complicity is not simply something that is imposed from without, as is the case with most instances of oppression. ${ }^{11}$ Rather, as we see elsewhere in The Second Sex, the unfreedom of complicity is something that is embraced from within. As Beauvoir puts it, woman "chooses to want her enslavement [son esclavage] so ardently that it will seem to her to be the expression of her freedom [liberte]" (684). ${ }^{12}$ Complicity is thus distinctive in being a form of unfreedom that is reinforced and perpetuated by unfree agents themselves, even if they are not the initial cause of this unfreedom. To fully grasp the richness of Beauvoir's account of complicity, we need to temper the emphasis on the dependent situation of woman with an attention to the active role agents can play in embracing and reinforcing their own unfreedom, something that can be done by drawing out the Heideggerian strands of Beauvoir's analysis.

\section{The Heideggerian Strands of Beauvoir's Analysis}

Beauvoir's philosophical framework is most often analyzed in its relation to the work of Jean-Paul Sartre and G. W. F. Hegel. However, as James argues, with regard to the notion of complicity, appeal to these philosophers fails to shed light on Beauvoir's distinctive analysis, and thus the question of her place in the history of philosophy remains open (James 2003, 152). James chooses to draw out the connection between Beauvoir's account of complicity and the work of republican theorists, but I argue a more fruitful analysis can be generated by turning to Heidegger. It is well known that existentialism owes an intellectual debt to Heidegger's philosophy, and in particular to Being and Time. But although the title of Sartre's Being and Nothingness is perhaps the most obvious homage to this text, in recent years scholars have drawn attention to the Heideggerian strands of Beauvoir's work. Both Nancy Bauer and Eva Gothlin have suggested that by appreciating Heidegger's influence on Beauvoir's writing we can gain a deeper understanding of her philosophy (Gothlin 2003; 
Bauer 2006), and it is in accordance with this insight that I pursue my interpretation of complicity.

One might think Beauvoir's initial characterization of complicity is distinctively Sartrean, as she describes complicity in terms of the "temptation of flee[ing] freedom" and the possibility of eluding the "anguish and stress of an authentically assumed existence" (Beauvoir 1949/2011, 10). But in making this jump, one ignores the Heideggerian roots of the ideas of authenticity, anguish (or anxiety), and a flight from freedom. As Gothlin argues, drawing out the Heideggerian connection in Beauvoir's work helps to demonstrate where she and Sartre come apart in their relation to Heideggerian ideas (Gothlin 2003, 45), and by taking seriously the Heideggerian influence on Beauvoir's thought, one can no longer assume Beauvoir is simply taking over and employing Sartre's existentialism, but instead must appreciate her as a thinker in her own right. ${ }^{13}$

To draw out the Heideggerian strands of Beauvoir's analysis is not to claim that she simply reproduces or passively employs Heideggerian ideas. Rather, I aim to draw attention to the active way in which Beauvoir can be read as making use of Heideggerian notions for her own purposes. ${ }^{14}$ To take seriously the Heideggerian influence on Beauvoir's philosophy is to bring to light new possibilities and insights in the work of both authors, possibilities that do not fully come to light without highlighting this connection. In particular, with regard to the notion of complicity, by attending to the Heideggerian aspects of Beauvoir's analysis, I aim to show that we are furnished with new ways of thinking about and interpreting what it is to be complicit in one's own unfreedom and why agents become complicit, as well as having implications for how such complicity may be addressed in real-world cases. In terms of thinking about Heidegger's texts, exploring the ways Beauvoir can be read as engaging with his philosophy has implications for how we think about Heidegger's work as a potential resource for feminists. ${ }^{15}$

In examining Beauvoir's understanding of complicity, I shall argue that her appreciation of the way situation can limit our freedom is far closer to Heidegger's understanding than to Sartre's. ${ }^{16}$ One sees this, for example, in Beauvoir's use of distinctively Heideggerian terminology like Mitsein, which she uses to develop her characterization of complicity. Beauvoir argues that "the tie that binds her [woman] to her oppressor is unlike any other," owing to an "original Mitsein"-literally "Beingwith" - that enforms her relation with man (Beauvoir 1949/2011, 9). This compound German word comes from Being and Time and signals the idea that Dasein (Heidegger's term for the human being and the human way of being) is always "with" Others, even if other Dasein are not physically present. Being-with can be read as an indication of Heidegger's relational understanding of Dasein's existence. It indicates the way our situation and our relations with others, as Lauren Freeman puts it, "not only help to constitute what we know, they also help to constitute an essential part of who we are, who we were and who we can become" (Freeman 2011, 370). Similarly, for Beauvoir the primordial Mitsein of man and woman helps to explain woman's existence as the Other in relational terms. Even if men are not physically present, the "necessary link connecting her to man" means that woman is never free from the 
domination that pervades her situation, informs her character and limits her possibilities and her freedom (Beauvoir 1949/2011, 10).

As I shall argue, the understanding of how our situation and our relations with others can influence our possibilities, and our possibility for freedom at an existential level, is an insight that Beauvoir and Heidegger share. But it is an insight that is unavailable to the Sartre of Being and Nothingness, who argues that our situation can never truly limit our freedom; insisting instead that it is "our freedom which constitutes the limits which it will subsequently encounter" (Sartre 1943/2003, 504). ${ }^{17}$ Focusing on the Heideggerian strands of Beauvoir's analysis will enable us to systematize her account of situation with the idea of woman's active complicity, giving a richer and more nuanced account of complicity than by appealing to either a republican framework or to Sartre's existentialism.

\section{Beauvoir and Heidegger: Situation and the Social Dimension of Complicity}

In the opening lines of her chapter on "Woman's Situation and Character," Beauvoir offers a summary of the indictments that have been made against women and that have "remained the same throughout superficial changes" since the time of the Greeks: 'She 'wallows in immanence,' she is argumentative, she is cautious and petty... she lacks morality, she is vulgarly self-serving, selfish, she is a liar and an actress" (Beauvoir 1949/2011, 638). Despite the consistency of this view of woman, Beauvoir argues that "the types of behaviors denounced are not dictated to woman by her hormones or predestined in her brain's compartments: they are suggested in negative form by her situation" (638). Here Beauvoir coheres with the Heideggerian and Sartrean notion of our existential—or to use Heidegger's term, "ontological"freedom: human existence is fundamentally free in the sense that we have no predetermined essence in accordance with which our life or our "character" unfolds. ${ }^{18}$ But contra Sartre, who concludes from this "the absolute freedom of human consciousness" (Gothlin 2003, 51), Beauvoir develops a more nuanced account, closer to Heidegger's understanding. For both Beauvoir and Heidegger, despite humans' existential freedom and lack of determination, our situation can still limit our possibilities and suppress our freedom.

As Beauvoir famously argued, "one is not born, but rather becomes, woman" (Beauvoir 1949/2011, 283). A key aspect of this becoming lies in her distinctive situation as the Other. Rather than being presented with a world of possibilities, Beauvoir argues that woman encounters the world as a "stubborn, indomitable resistance" (639). Whereas man is free to manipulate his surroundings and pursue his own goals, woman finds herself restricted by her situation and the dominant understanding of her as the Other, which serves to undermine and suppress her existential freedom. Exactly how this is supposed to occur can be illuminated by considering Heidegger's account of Dasein's existence in division I of Being and Time. Although Dasein is fundamentally free at an existential or "ontological" level, division I of Being and Time concerns itself with Dasein in an "inauthentic" mode of existence. This analysis, as 
Sacha Golob argues, is "Heidegger's attempt to understand one of the central and distinctive ways in which Dasein may fail to be free" (Golob 2014, 245). ${ }^{19}$

A key aspect of inauthentic, unfree modes of existence is our tendency to "fall into das Man," that is, to be absorbed in the social world and the dominant-if misleading — way that things are understood (Heidegger 1927/1962, 220). Das Man is Heidegger's term for the social world, the normative sphere, consisting of the behaviors, practices, and social roles that direct and shape our everyday existence. Moreover, as with Beauvoir's understanding of situation, das Man also shapes the way we first encounter others and come to understand ourselves (167). The way we are first opened onto ourselves and others by das Man is in terms of social roles. ${ }^{20}$ This way of understanding ourselves and others is misleading because it obscures our existential or "ontological" freedom. ${ }^{21}$ It is a self-relation in which we come to understand our existence as fixed, viewing our behavior as determined by the social role or archetype in terms of which we are understood on the basis of, for example, our gender, race, or ethnicity. Nancy Holland exemplifies this phenomenon in her discussion of the gendered scripts of das Man and how they limit the ways women can understand themselves and what they believe they are capable of. As she argues, "the traditional upper- or middle-class script for women ends with marriage and motherhood. Once that happily-ever-after is accomplished, there is nothing more for a woman to do with her life" (Holland 2001, 136). Such limiting "scripts" or social roles are not simply ones that women freely adopt from a range of possibilities that may be more or less restrictive. Rather, das Man is described by Heidegger as a "dictatorship," "prescrib[ing] what can and may be ventured" (Heidegger 1927/1962, 164-65). Heidegger's account of falling into das Man is not analogous to the Sartrean notion of bad faith. ${ }^{22}$ It is not an account of the artificial obstacles we put in our own way, obstacles that can never really constrain us or limit our freedom. Rather, Heidegger's account of das Man speaks to the way oppressive social settings can play a central role in restricting our self-understandings and what we believe we are capable of, thereby limiting our possibilities for existence and suppressing our existential freedom. $^{23}$

With regard to the situation of woman, we can say that the das Man of Western patriarchy disseminates the view of woman as Other, promoting it as the primary way in which woman should be understood and should understand herself. Through prescribed narratives, social roles, or to use Beauvoir's term, "myths," woman comes to understand that she is - and has always been - the Other (Beauvoir 1949/2011, 639), and thus what she can do or be is limited in line with this (self-)understanding. Despite the fact that these myths or female identities are multiple and often contradictory, Beauvoir claims that they are all at base an articulation of woman as Other (162). To get outside of such an understanding and live other than as Other would involve rejecting the dominant narratives of society and the shared and "agreed upon" understanding of what it is to be a woman, which, as both Beauvoir and Heidegger recognize, is a very difficult thing to do. In her discussion of the liberated woman who has partially resisted her complicity, Beauvoir still notes the continued pressure on her to adhere to the standards of femininity (724). Similarly for 
Heidegger, das Man is said to shut down alternative understandings that do not fit the dominant narrative "keep[ing] watch over everything exceptional that thrusts itself to the fore" (Heidegger 1927/1962, 164-65).

For both Beauvoir and Heidegger, human agents are fundamentally free and undetermined at an existential level. However, in any given concrete manifestation of a human agent, this fundamental freedom may be effectively denied by the particular situation in which agents find themselves. The central role of das Man in Heidegger's account of Dasein's everyday unfreedom illuminates Beauvoir's account of the role oppressive situations can play in alienating women from their own freedom. It goes beyond the Sartrean account in its understanding of how situation can serve to occlude and suppress our existential freedom. ${ }^{24}$ But it also goes beyond the republican interpretation. Rather than concluding that the oppressive social setting offers the whole explanation for woman's complicity in her own unfreedom, attending to the Heideggerian strands of Beauvoir's account enables us to integrate this analysis with an understanding of the way in which agents can be active in embracing their own unfreedom, therefore doing justice to the idea that woman "chooses to want her enslavement" (Beauvoir 1949/2011, 684).

\section{Active Complicity}

Although Beauvoir recognizes that woman is cast into the position of the Other by man, she also discusses the way women can cling to their chains, embracing their role as Other and thereby reinforcing their own unfreedom. Beauvoir describes woman as "actively playing the role of passivity" (Beauvoir 1949/2011, 654), arguing that man "wants her to be object: [so] she makes herself object" (653). These descriptions demonstrate that woman's existential freedom is not totally eclipsed in such acts of self-objectification, since making oneself an object is the expression of "a free activity... the most docile, the most passive woman is still consciousness" (653). But these descriptions also serve another purpose; they demonstrate that woman is active in reinforcing and upholding her position as the Other and helping to perpetuate her own unfreedom: she makes herself an object, she actively plays the role of passivity. Once again, we can gain a systematic understanding of this phenomenon by turning to Heidegger.

Heidegger doesn't just argue that Dasein falls into das Man; he argues that Dasein "flees" into it (Heidegger 1927/1962, 229). To focus on the Heideggerian strands of Beauvoir's analysis is thus to take seriously the idea that agents who are complicit in their own unfreedom actively embrace unfree ways of life. If the power and influence of das Man meant that Dasein could not free itself from das Man's limited and limiting grasp, ${ }^{25}$ then Heidegger's account of das Man would not feed into an account of complicity. Rather, it would be an account of structural oppression. Although falling is an ontological constituent of Dasein's being, that is, it is an essential feature of human existence (224), Dasein can respond to falling in one of two ways: Dasein can give in, or it can resist. ${ }^{26}$ That is, it can flee from its existential freedom and 
embrace the dominant, restrictive social understandings of das Man; or it can struggle against these distorted understandings and seek to "discover the world in its own way" (167). One finds a similar account in The Second Sex where Beauvoir argues that to overcome her complicity in her own unfreedom, "there is no other way out [for woman] than to work for her liberation" (Beauvoir 1949/2011, 664). For Beauvoir, woman's complicity involves a kind of "resignation" to the unfreedom of her current situation, accepting and even embracing unfreedom by "think[ing] that neither people nor things can be different from what they are" (642). Similarly, Heidegger characterizes the unfreedom of inauthenticity as the state from which Dasein must emerge. $^{27}$

Although our existential freedom may be more or less occluded by the particular situation in which we find ourselves, in most cases agents themselves play a central role in accepting and even embracing their own unfreedom. ${ }^{28}$ In such cases, the dependent, oppressive situation of woman is not the cause of this acceptance, as the republican interpretation of complicity suggests. Rather, Beauvoir and Heidegger both develop explanations for why agents embrace their own unfreedom with regard to the "benefits" of complicity and their particular understanding of agents' relation to their own freedom. Rather than assuming people will naturally gravitate toward freedom as long as there is no "blockage," this assumption is precisely what is at issue in the work of both Beauvoir and Heidegger.

\section{The Benefits of Complicity}

As we have seen, Beauvoir argues that "[r]efusing to be Other, refusing complicity with man, would mean renouncing all the advantages an alliance with the superior caste confers on them [women]" (Beauvoir 1949/2011, 10). If woman complies with her role as the Other she may be rewarded with social approval, admiring suitors, a rich husband, a big house. But underlying such social and material benefits are the metaphysical benefits of complicity. Beauvoir argues that complicity in her role as Other enables woman to "[elude] the metaphysical risk of freedom that must invent its goals without help" and avoid "the anguish and stress of authentically assumed existence" (10). For Heidegger, such "benefits" are also central in his explanation of why Dasein "flee[s] in the face of itself and in the face of its authenticity" (Heidegger $1927 / 1962$, 229), embracing and falling back onto the self-(mis)understandings promoted by das Man and the unfreedom they entail.

Heidegger argues that Dasein is the entity for whom its being is always an issue (Heidegger 1927/1962, 32). Rather than having an essence in accordance with which its life unfolds, "the essence of Dasein lies in its existence" (67), meaning that Dasein "creates its essence" through existing: the choices we make and what we do are the only things that ultimately define who we are. As a result, existence, or in other words the issue of Dasein's being, "become[s] manifest as a burden [Last]" (173). Because there is nothing to determine Dasein, it has to take ultimate responsibility for its existence, and this is a frightening prospect. 
Similarly, for Beauvoir, on a metaphysical level all human beings are characterized by an ambiguous pull between transcendence: that which manifests my existential freedom, my lack of essence and my ability to choose my projects, and immanence: my objectification, the facts of my material situation, being acted upon rather than acting. Such ambiguity is troubling, and thus woman-like man-attempts to "resolve" her own existential ambiguity. ${ }^{29}$ The particular way in which woman does this, however, is conditioned by the limits of her situation. Woman's situation as the Other contradicts her ambiguity - her worldly possibilities are limited to being an object, a thing, rather than a subject. Therefore the particular way in which women attempt to "resolve" their ambiguous existence often takes the form of "trying to justify their existence within their own immanence, that is to achieve transcendence through immanence" (Beauvoir 1949/2011, 664). Rather than resisting unfreedom and "refus[ing] the limits of her situation," woman embraces her role as the Other in an attempt "to convert her prison into a heaven of glory, her servitude into sovereign freedom" (664). Ultimately, in an attempt to resolve the ambiguity of her existence, woman ends up reiterating the patriarchal narrative of woman as Other and thus reinforcing her own, as well as other women's, social and material unfreedom. This account does not exempt women from responsibility regarding their complicity in their own unfreedom. As Beauvoir argues, "if woman discovers herself as the inessential and never turns into the essential, it is because she does not bring about this transformation herself' (8). But it does enable us to acknowledge that the particular way in which complicity manifests itself will be influenced by our situation.

We find a similar account in Being and Time, where das Man plays a key role in Heidegger's explanation of how Dasein flees the burden of its own existence. Heidegger argues that das Man "accommodates" and "disburden[s]" Dasein (Heidegger $1927 / 1962,165)$. One way in which das Man does this is by enabling Dasein to filter its agency through social roles. Rather than Dasein deciding for itself how to act, Dasein defers this onto the prescriptive scripts and social roles disseminated by das Man, binding itself unquestioningly to particular norms and dominant social interpretations of its existence. In the case of woman, by embracing her role as Other and resigning herself to her oppressive situation as if it were something she had freely chosen, she further alienates herself from the existential freedom her social context has already sought to suppress. Contrary to the republican interpretation, woman's oppressive situation is not the cause of her flight from freedom. Woman's situation only explains the form her fleeing takes; it does not offer the full explanation for why she flees. However, this does not mean Beauvoir simply reproduces the Sartrean analysis of bad faith. Although Heidegger's characterization of fleeing the burden of existence may form the basis of bad faith, in Heidegger's hands our flight from freedom is not only explained in terms of an individualistic attempt to evade our lack of essence and the ultimate responsibility we must take for ourselves. Instead it enables us to appreciate that the way we flee our existential freedom can have consequences for our social and material freedom. And, vice versa, our social and material freedom can have consequences for our ability to live in light of, and exercise, our existential freedom. 


\section{ACCOUNTING FOR WOMEN'S EVERYDAY UNFREEDOM}

Although Beauvoir argues explicitly that women are complicit in their own unfreedom, she also observes that such a tendency is "common even in men... destined like the woman to the repetition of daily tasks, alienated in ready-made values, respecting public opinion, and only seeking vague comforts on earth" (Beauvoir 1949/2011, 661). Similarly, for Heidegger, it cannot be that women, in virtue of some facet of their existential make-up, are more complicit than men, because Heidegger does not distinguish between men and women at an ontological level. In The Metaphysical Foundations of Logic, Heidegger makes it clear that the "neutrality" of the term Dasein is not coincidental, but is "essential, because the interpretation of this being must be carried out prior to every factual concretion" (Heidegger 1928/1984, 136). Every claim Heidegger makes about Dasein is meant to be a claim that pertains to all people, men and women, regardless of factical matters such as gender, race, class, or sexuality. However, this does not mean we cannot acknowledge that at an everyday level, complicity appears to be distinctive of women's situation and that in their everyday existence, women, on the whole, appear to be more unfree than men.

As I have argued, both Beauvoir and Heidegger offer a relational picture of human existence. The specific situations into which we are thrown and the relations we have with others have a real effect on our freedom because our situation can limit our possibilities, and our possibilities are what we fundamentally are. As Beauvoir puts it:

Woman is not a fixed reality but a becoming; she has to be compared with man in her becoming; that is, her possibilities have to be defined: what skews the issues so much is that she is being reduced to what she was, to what she is today, while the question concerns her capacities; the fact is that her capacities manifest themselves clearly only when they have been realized. (Beauvoir 1949/2011, 45-46)

Similarly, for Heidegger, "Dasein is its possibility" (Heidegger 1927/1962, 68). Dasein has no fixed essence and must be understood in terms of what it could do or become. However, in falling into the social world of das Man, "Dasein drifts along towards alienation [Entfremdung]... this alienation closes off from Dasein its authenticity and possibility, even if only the possibility of genuinely foundering" (222). For both Beauvoir and Heidegger, the more possibilities we have, the freer we are, because possibilities are that in terms of which our existential freedom manifests itself. A middle-class woman living in a privileged, Euro-American context is freer than a woman living in a harem under an oppressive patriarchal regime, because the woman in the EuroAmerican context has more opportunities to express and live out her existential freedom owing to the wider field of possibilities, opportunities, and choices that are open to her. As Beauvoir puts it, "the possible does not exceed the real" (Beauvoir 1949/ 2011, 270). For women to be able to realize their existential freedom, there must be genuine worldly possibilities in which they can do so.

One finds this idea articulated in Heidegger's own philosophy where he argues there has to be a certain "match up" between the possibilities of existence we project 
and possibilities that are available to us in the world. In History of the Concept of Time, Heidegger discusses "pseudo-understanding": "a semblance of understanding, a look-alike, as though this incomprehension were still genuine comprehension" (Heidegger 1925/1985, 260). Consider Don Quixote: he may understand himself as a knight and even attempt to carry out certain tasks that reflect this understanding, but nevertheless he is not a knight. What this tells us is that (self-)understanding is not simply something "in my head," but extends beyond the isolated individual and necessarily involves the world. In order to count as free, woman cannot just understand herself as free or attempt to behave as if she were free in situations that contradict her freedom. The woman who tries "to achieve transcendence through immanence" is described by Beauvoir as "ridiculous" and "pathetic" (Beauvoir 1949/2011, 664) because she fails to engage with reality. ${ }^{30}$ She does not achieve genuine freedom, but only deceives herself that she is free in a situation that undermines and contradicts her freedom (664), thereby further alienating herself from the freedom her social context has already sought to suppress. In order to count as genuinely free, women must have real-world possibilities through which they can express their existential freedom. However, in the situation of women under patriarchy that Beauvoir describes, such possibilities are often denied to women or at least severely curtailed.

On this reading we can say that both men and women may flee their existential freedom and absorb themselves in the misleading scripts and roles disseminated by das Man. However, the social roles in which women immerse themselves, and the scripts with which they come to identify, are more limited, limiting, and more obviously oppressive and incompatible with their social and material freedom and thus with their ability to express their existential freedom, than the roles and identities that are open to men. Therefore, in contrast to men, in identifying with such roles, women appear (more) complicit in their own unfreedom and are genuinely more unfree in their everyday existence than their male companions. On this account we need not say that women have a greater tendency toward complicity than men, but only that when women are complicit this has greater negative effects for them. For example, the man who understands himself as essentially defined by his role as the patriarchal head of a household may be as complicit in fleeing from, and concealing from himself, his existential freedom as the woman who understands herself as essentially a subservient housewife, since both ignore the contingency of social narratives and take their social roles to be essentially binding on them. ${ }^{31}$ Nevertheless, we can still say that the subservient housewife is less free than the patriarch in her dayto-day life, because the content of her social role and its concomitant norms, expectations, and behaviors are more limited and limiting than those associated with the role of the patriarch.

\section{Refining the Account of Active Complicity}

What this analysis implies is that we must revise our understanding of complicity from something distinctive of woman's situation, or as some kind of pathological 
anomaly, to an understanding of complicity as a more everyday phenomenon and as something of which we are all at risk of falling foul. On the interpretation I have developed, complicity is best understood in terms of a dual analysis, involving an understanding of the oppressive social context of the agent as well as an understanding of the attitudes the agent has toward the dominant social roles, narratives, and norms that are prescribed to them. In terms of this second element, we can say that a key aspect of complicity is agents' tendency to absorb themselves in social roles and relate unquestioningly to the ways of understanding themselves prescribed to them by their social context. ${ }^{32}$ We see this clearly in the "imprisoned woman who [attempts to] convert her prison into a heaven of glory, her servitude into sovereign freedom" (Beauvoir 1949/2011, 664). Rather than resisting or questioning her situation and the oppressive social narratives and self-understandings that are prescribed to her, she accepts and embraces her position as the Other as if it were something she had freely chosen. This tendency to accept and embrace social roles and narratives even when they may restrict our freedom, is explained by the analysis developed in the second and third parts of section II ("Active Complicity" and "The Benefits of Complicity") regarding our tendency to flee from our existential freedom and the attitudes that enable such flight. ${ }^{33}$

Beauvoir describes women who are complicit in their own unfreedom as having attitudes of "acceptance" and "resignation" in relation to their situation of subordination and the understanding of themselves as the Other (Beauvoir 1949/2011, 642). Having these attitudes means that rather than resisting their oppressive situation they accept it with a "calm stubbornness... "think[ing] that people nor things can be different from what they are" (642). Similarly, Heidegger argues that inauthentic, unfree modes of existence are characterized by an attitude of "stubbornness [Versteifung] about the existence one has achieved" (Heidegger 1927/1962, 308, translation modified). This stubbornness leads Dasein to take the social roles and self-understandings presented to it by das Man as somehow unquestionable and essentially binding on $\mathrm{it}^{34}$ thereby concealing from itself its existential freedom and the understanding that the only norm binding on Dasein qua Dasein is that "there are no norms binding on Dasein qua Dasein" (Golob 2014, 239).

We can understand the stubborn way Dasein relates to dominant social narratives as an example of active complicity. For Heidegger, the reason that Dasein becomes stubborn with regard to its current existence and the roles, narratives, and behaviors prescribed to it, is that stubbornness enables Dasein to remain absorbed in das Man. As we saw in the third part of section II ("The Benefits of Complicity"), absorption in das Man enables Dasein to disburden itself of the issue of its own being and the ultimate responsibility it must take for itself. Through its stubbornness Dasein turns away from its existential freedom by taking the social roles and dominant narratives prescribed by das Man to be definitive of its own existence, essentially binding on it, and thus unchallengeable. ${ }^{35}$ Being stubborn with regard to the social roles and narratives in terms of which Dasein currently understand itself can thus be interpreted as a central way in which Dasein flees the burden of its own existence and becomes complicit in its own unfreedom. 
One finds a similar account in The Second Sex where Beauvoir argues that "resignation [to one's oppressed position] is only a surrender and an evasion" (Beauvoir 1949/2011, 664). Attitudes of resignation, acceptance, and stubbornness with regard to one's current existence mean that women conceal from themselves the possibility of resistance. They therefore become complicit in perpetuating the unfreedom of their current situation because they do not believe it could be any different and thus do not strive to resist it. But such resignation is not simply the passive acceptance of one's oppressed position. Rather, Beauvoir argues that “woman's faults are amplified all the more to the extent that she will not try to combat them but, on the contrary, make an ornament of them" (654). Rather than passively acquiescing to her oppressive situation and the dominant social understanding of her as the Other, Beauvoir paints a picture of woman as actively and stubbornly embracing this position. ${ }^{36}$ Returning to Beauvoir's metaphysical understanding of human existence, ${ }^{37}$ we can view woman's stubbornness and resignation as an attempt to resolve the ambiguity of her existence by reifying it in terms of a fixed social position or dominant social narrative. For Beauvoir, as for Heidegger, attitudes of stubbornness and resignation can be understood as a central way in which active complicity manifests itself.

\section{An Examination of the \#MeToo Backlash}

Highlighting the ways in which Beauvoir can be read as employing Heideggerian ideas in service of her analysis of complicity, enables us to give equal consideration to the coercive social world with its tendency to direct us into unfree ways of being, and to the active role of agents in fleeing their freedom and embracing unfreedom. The analysis of complicity I have outlined can thus account for cases where complicity may be almost inevitable, owing to the extreme oppression and restriction of the agent's social setting, and yet we find defiant agents who are not simply the passive victims of their oppressive circumstances. ${ }^{38}$ But it can also account for cases where the social setting of the agent does not appear to offer the full explanation for their complicity — such as in the case of privileged, wealthy, European women like Deneuve and Wyatt - and yet agents still act to reinforce rather than resist their own unfreedom. ${ }^{39}$

In analyzing the \#MeToo backlash it cannot be taken for granted that comments like Wyatt's and Deneuve's are simply the result of their oppressive social setting. This does not give enough agency to the women themselves, nor does it acknowledge the role that an agent's own attitudes and self-understandings can play in shutting down or opening up particular possibilities. Although patriarchy provides the context for the development of their views and a certain pressure to adhere to or reiterate them, Deneuve's and Wyatt's privileged social and material status by no means makes it inevitable that they will simply reproduce patriarchal narratives about sexual objectification. Indeed, their financial, educational, and class privileges arguably buy them a certain distance from the necessity of such reproduction. ${ }^{40}$ And yet, they continue to espouse views that reinforce their own unfreedom and the unfreedom of other 
women by contributing to a social context in which sexual harassment is trivialized and deemed acceptable. In order to fully understand the complicity of Deneuve and Wyatt, then, we must attend not only to their social setting, but also to how these women play an active role in reinforcing their own unfreedom, ${ }^{41}$ in Beauvoir's terms, how they do not simply have sexual objectification forced upon them, but how they seem to "[choose] to want" it (Beauvoir 1949/2011, 684).

Deneuve's and Wyatt's active complicity is manifested in their attitude toward sexual harassment and what this reveals about the way they understand themselves and women more generally. Contra the \#MeToo movement, Deneuve "defend[s] a freedom [for men] to bother as indispensable to sexual freedom," and argues that movements like \#MeToo express a "hatred of men and sexuality" (Deneuve 2018a). Meanwhile, Wyatt defends unsolicited groping as "flatter[ing]" (Wyatt 2017). Both women appear stubborn with regard to the patriarchal status quo and the understanding of women in general (and themselves) as sexual objects. They refuse to give up narratives that trivialize sexual harassment, or present it as something other than a necessary part of courtship. There may be many reasons for these attitudes. We can observe that to destabilize norms, ideas, social dynamics, and roles that have become central to one's self-understanding and to grasping one's position in the world and one's relation to others can be a very unnerving thing to do, and thus it may be something that people understandably resist. ${ }^{42}$

Moreover, the unseating of dominant narratives and self-understandings may be even more strongly resisted if revising one's self-understanding also involves recognizing one's powerlessness. Deneuve's narrative in particular stresses that she takes the \#MeToo movement as one that is "claiming to promote the liberation and protection of women, only to enslave them to a status of eternal victim" (Deneuve 2018a). On this reading, one can see Deneuve's and Wyatt's attitudes as part of a strategy of complicity, a misguided attempt to avoid the reality of their oppressive situation and "empower" themselves by identifying with their position as Other. ${ }^{43}$ However, as we saw in the fourth part of section II ("Accounting for Women's Everyday Unfreedom"), in so doing they do not engage with reality and so only end up deceiving themselves about their freedom. By presenting their oppressive situation to themselves as something they desire (Wyatt), or as something liberating (Deneuve), we can understand Deneuve's and Wyatt's attitudes and comments as a stubborn reluctance to give up the dominant social narratives in terms of which they understand themselves.

On this account, although Deneuve and Wyatt may be active in their complicity, we need not claim that they are conscious of this. Indeed, for social roles and dominant social narratives to be able to function as they do, we must conceal from ourselves the tension that lies at the heart of them. ${ }^{44}$ Rather than experiencing themselves as deceiving themselves about the reality of sexual harassment, Deneuve and Wyatt may understand themselves as simply being "realistic" or practical. ${ }^{45}$ But, in following the Beauvoirean analysis of complicity I have outlined, we can see the acceptance of sexual harassment and the "resignation" to a world in which it is just part of everyday life, not as a pragmatic approach, but as "a surrender and an 
evasion" (Beauvoir 1949/2011, 664). It is a flight from the possibility of resistance and manifests Deneuve's and Wyatt's active complicity in accepting and helping to perpetuate the idea of women as sexual objects, an understanding of women that limits their social and material freedom and suppresses their possibility to express and live in light of their existential freedom.

On the interpretation I have developed, the way in which complicit agents are active in their own complicity can be understood as a kind of self-deception, resulting from a reluctance to destabilize the norms, self-understandings, and social roles in which agents have immersed themselves. Rather than problematizing and putting into question limiting social roles and dominant social narratives, the complicit agent becomes stubborn with regard to these. Interpreting complicity in terms of a dual analysis involving the oppressive roles and narratives prescribed by one's social situation, and a reluctance on the part of the agent to put these into question, enables us to develop a more nuanced analysis of cases like Deneuve's and Wyatt's by offering us reasons and explanations beyond their social setting for why these women may have become complicit in reinforcing their own unfreedom. The aim of this analysis is not necessarily to establish that we have more reason to blame Deneuve and Wyatt for their complicity than women in more oppressive circumstances with less opportunity to resist. Rather, the aim has been to better understand the different ways in which complicity can manifest itself and the different reasons why agents may become complicit, as well as what mechanisms may be at play in agents remaining complicit. My aim in developing this analysis has thus been to put us in a better position to address and overcome gendered complicity in all of its forms, and move toward feminist liberation.

\section{Analyzing and Overcoming Complicity: Toward a Dual Approach}

Drawing out the Heideggerian strands of Beauvoir's analysis means that complicity is not reduced to a kind of structural oppression and explained simply in virtue of the pressures of the unjust social setting forcing women into complicit ways of life by giving them no other option than to be complicit in their role as Other and the unfreedom it entails. Nor does the Heideggerian approach take the republican route and assert that the situation of subordination and domination in which women find themselves distorts their psychology so that they accept unfree ways of life that they would not otherwise choose, an approach that relegates comments about the metaphysical benefits of complicity to a secondary status. But it also does not reduce complicity to a Sartrean analysis of bad faith, ignoring the pressures of the social world to understand ourselves in ways that alienate us from our fundamental freedom. Rather, focusing on the Heideggerian strands of Beauvoir's analysis achieves a synthesis of the Sartrean and the republican interpretations of complicity, incorporating the strengths of both while going beyond what each offers in isolation. Highlighting the ways in which Beauvoir can be understood to employ Heideggerian notions in service of her analysis of complicity enables us to preserve the virtues of James's republican 
interpretation, while integrating this with Beauvoir's notion of active complicity and her claim that woman "chooses to want her enslavement" (Beauvoir 1949/2011, 684) to ultimately produce a richer and more nuanced analysis of complicity that nevertheless remains faithful to Beauvoir's original text.

But beyond its appropriateness as an interpretive tool, we can see that focusing on the Heideggerian strands of Beauvoir's analysis will have consequences, both for how we conceive of complicity and for how we think it will be overcome. In analyzing the potential complicity of an agent, attention will need to be paid to how agents understand themselves and relate to the social roles, norms, and dominant narratives prescribed by their social settings: whether they have stubbornly resigned themselves to these, or whether they have resisted complicity by being open to new understandings of themselves and their situation that may be more able to reflect their own existential freedom. On the account I have developed, it will not be assumed that the particular way of understanding and relating to themselves that agents have is necessarily caused by their social setting. Rather, the Beauvoirean approach to complicity I have outlined acknowledges that there can be other motivations and mechanisms at play in explaining why people understand themselves and relate to particular roles, norms, and narratives in the way that they do. This implies that overcoming complicity will be a twofold process, requiring changes in the oppressive social setting of agents and in agents themselves. Beauvoir indicates this in the conclusion to The Second Sex, where she argues that liberation will involve the attainment of "perfect economic and social equality" with men and an "inner metamorphosis" that will stop women from actively embracing their own unfreedom (Beauvoir 1949/2011, 764). Since both the oppressive situation of agents and agents themselves play an active role in the explanation of complicity, both aspects must be addressed directly in its resolution. It cannot be assumed that a change in agents' external situations will necessarily lead to a change in agents' attitudes and selfunderstandings. ${ }^{46}$ By attending to the Heideggerian strands of Beauvoir's analysis we are able to see more clearly why this dual approach is necessary, and thus are better placed to analyze the ways in which some women may be complicit in reinforcing their own unfreedom, as well as the strategies by which this unfreedom may be successfully overcome.

\section{NOTES}

1. This definition should be distinguished from more legalistic understandings of complicity such as Christopher Kutz's. For Kutz, complicity refers to "cultural and legal practices, surrounding relations of an agent to a harm that are mediated by other agents" (Kutz 2000, 2). My concern, however, is with the way agents can directly contribute to their own unfreedom. I elaborate this further in the second part of section I ("The Limitations of the Republican Interpretation").

2. I use the phrase "complicity in one's own unfreedom" rather than "complicity in one's own oppression" because the notion of oppression suggests an identifiable 
oppressing agent (Haslanger 2004, 98). However, in cases of complicity, "the line between oppressor and oppressed is far from unambiguous" (Kruks 2012, 56). I take unfreedom to encompass cases of oppression, but to allow for a broader scope of analysis. I discuss this further in the second part of section I ("The Limitations of the Republican Interpretation").

3. Although Beauvoir's analysis does still speak to the way in which women are oppressed on the basis of their gender in a patriarchal society, an important worry is that her analysis privileges gender over other forms of oppression and is blind to issues of intersectionality. For a detailed discussion of these issues, see Gines 2014.

4. Like Beauvoir, I use the term woman "to refer to no archetype, to no immutable essence; 'in the present state of education and customs' must be understood to follow most of my affirmations" (Beauvoir 1949/2011, 279). Moreover, the use of "woman" does not mean Beauvoir erases the differences between women. See Kruks 2012, 67-71.

5. I discuss this further in section II.

6. James's is the only detailed analysis of Beauvoirean complicity I know of. Kruks briefly discusses complicity, but within the broader context of an analysis of oppression in Beauvoir's work (Kruks 2012, 71-74).

7. Beauvoir's conception of women's slavery is usually understood in the context of Hegel's master-slave dialectic, to which Beauvoir explicitly draws a parallel (Beauvoir 1949/2011, 74). One key omission in Beauvoir's slave analogy, Kathryn Gines and Sabine Broeck both argue, is that she does not develop the woman-as-slave analogy in the context of institutional slavery, thus ignoring women who were literal slaves and codifying women in her account as implicitly white. For detailed discussions of slavery in The Second Sex, see Gines 2014, esp. 261-66; and Broeck 2011.

8. For example, woman's situation of dependence means "she struggles for forms of self-respect that are precarious and liable to be self-defeating" (James 2003, 165).

9. On the notion of active complicity see Kruks 2012, 72.

10. Sonia Kruks also makes this point (Kruks 2012, 71).

11. Sally Haslanger defines oppression in terms of "an agent or agents misusing their power to harm another" (Haslanger 2004, 98) thus suggesting an external oppressing agent.

12. I take "choosing to want her enslavement" to describe how woman comes to identify with and embrace the situation of Otherness and unfreedom described in section I. I develop this analysis further in the third part of section II ("The Benefits of Complicity").

13. As Kruks argues, "The Second Sex is to a significant degree philosophically incompatible with Being and Nothingness" (Kruks 1987, 111).

14. This is similar to the way in which Bauer understands Beauvoir as actively engaging with the ideas of canonical figures, in particular Sartre and Hegel. See Bauer 2001, 182.

15. For the most part, Heidegger's work has been overlooked in this respect, although with a few notable exceptions. For feminist engagements with Heidegger's later work on language, see Graybeal 1990; and on nature, see Bigwood 1993. Feminist engagement with Heidegger's early work tends to take the form of articles, rather than more sustained investigations. See, for example, the first four chapters of Holland and 
Huntington, 2001, as well as Guenther 2008 and Freeman 2011. Of this list, Freeman's is perhaps the best example of a work that tries to appropriate Heidegger's philosophy for feminist ends.

16. I refer here and throughout the article to Sartre's early philosophy and in particular to his understanding of freedom and situation in Being and Nothingness. The difference in Sartre's and Beauvoir's understanding of situation and its relation to freedom is also noted by Kruks 1987, 111, and Gothlin 2003, 51.

17. In Sartre's later work he revises his understanding of the relation between situation and freedom, bringing him closer to the Beauvoirean and Heideggerian understandings.

18. Just as for the existentialist, "existence precedes essence," for Heidegger, "the essence of Dasein lies in its existence" (Heidegger 1927/1962, 67).

19. For a detailed discussion of freedom and its relation to authenticity, see Golob 2014

20. Although Heidegger does not explicitly refer to social roles when describing Dasein's self-understanding in das Man, this is a common way of interpreting Heidegger on this point. See Dreyfus 1991, 20-24.

21. Hans Bernhard Schmid makes a similar point: "being oneself and playing a social role are in fundamental tension with one another ... playing any role involves a basic self-misapprehension, or self-misunderstanding" (Schmid 2017, 264).

22. For example, Sartre's waiter exhibiting bad faith by enslaving himself to his alarm clock and "behaving as if it were not [his] free choice to get up each morning at five o'clock or to remain in bed" (Sartre 1943/2003, 83).

23. I discuss this further in the fourth part of section II ("Accounting for Women's Everyday Unfreedom").

24. Again, I refer to the Sartre of Being and Nothingness.

25. This does not mean that freedom and authenticity can be found by isolating oneself from the social world. Rather, it means that in free and authentic modes of being, Dasein develops a new relation to das Man. On this point, see Knowles 2017.

26. Taylor Carman also makes this point (Carman 2000).

27. Stephen Mulhall makes the similar point that the freedom of authenticity must always be understood as an "achievement" (Mulhall 2005, 73).

28. In some cases-like Beauvoir's example of women in a harem (quoted in Kruks 1987, 111) - our oppressive situation may completely cut us off from the possibility of realizing our existential freedom. These women are not considered complicit, as there is no real possibility of resistance. But the harem example is not representative of the more "everyday" situations in which Beauvoir is primarily interested.

29. Attempting to "resolve" ambiguity, either by identifying with pure immanence or pure transcendence, is always wrongheaded. Rather, one must reconcile oneself to the ambiguity of human existence.

30. Kruks makes a similar point (Kruks 1987, 116).

31. Thereby they view their existence as fixed and alienate themselves from their existential freedom.

32. To relate unquestioningly to one's social roles does not necessarily mean one does not examine or interrogate them at all. As Heidegger argues, one can engage in "the 
most exaggerated 'self-dissection"' and still fail to question one's identity in a fundamental way (Heidegger 1927/1962, 222). To relate unquestioningly to one's roles thus means that one does not question them in the right way, that is, in a way that would reveal the inadequacy of dominant social narratives and roles for capturing what is central to our existence-namely that we are fundamentally free at an existential level and thus no social role can ever be binding on us or fully capture what we are.

33. Again, these attitudes are not caused by the agent's social context, but are explained in terms of the analysis of the benefits of complicity developed in the third part of section II.

34. William Blattner also makes this point (Blattner 2013, 326).

35. It should be noted that my analysis does not deny that social roles play an important part in understanding ourselves and how we live in the world, nor does it claim that to manifest one's existential freedom one has to forgo all social roles. Overcoming complicity will not mean rejecting all social roles. Rather, it will involve developing a new relation to one's roles and the narratives that structure one's self-understanding. In the case of particularly oppressive social roles that restrict one's social and material freedom, it may mean rejecting these roles and narratives in favor of ones that are more compatible with the expression of one's existential freedom. However, the key aspect of the transformed relation to one's social roles is a recognition of their contingency, which is necessary in order to grasp one's own existential freedom. For an indication of what this transformed relation to one's social roles might look like, see Knowles 2017.

36. One finds a similar argument in the work of Mary Wollstonecraft, who argues that "[t]aught from their infancy that beauty is a woman's sceptre, the mind shapes itself to the body, and, roaming round its gilt cage, only seeks to adorn its prison" (Wollstonecraft 1792/1994, 112).

37. See the third part of section II ("The Benefits of Complicity").

38. On the republican account, where agents' situation of dependence is the primary focus in the explanation of their complicity, it seems difficult to account for agents who, although existing in the same oppressive social context, are not themselves complicit in their own unfreedom.

39. Kruks argues that Beauvoir sees complicity as particularly pervasive among middle-class, European women (Kruks 2012, 71). See also Beauvoir's claims that "women of the high bourgeoisie and aristocracy ... do not hesitate to radically sacrifice their autonomy as human beings ... they parrot conventional wisdom, they identify with the ideal imposed on them by the male code" (Beauvoir 1949/2011, 663).

40. At the outset of The Second Sex, Beauvoir describes women's everyday unfreedom in terms of their unequal socioeconomic status, and particularly women's financial dependence on men (Beauvoir 1949/2011, 9), presenting this as an important factor in explaining women's complicity. Similar arguments can be found in the work of other female writers of the time, such as Virginia Woolf, who also sees financial independence as removing, or at least lessening, the necessity of conforming to male expectations and patriarchal norms. See Woolf 1928/2000, 39.

41. As we see with the case of Deneuve and Wyatt, although financial independence may remove the necessity to conform to patriarchal narratives, financial independence alone does not necessarily guarantee that one will no longer reproduce such narratives. 
42. Ann Levey makes a similar point (Levey 2005, 131). Moreover, although Beauvoir ultimately calls for "revolt" if women are to be liberated, she acknowledges that this is a frightening prospect and impossible if not pursued "collective[ly]" (Beauvoir 1949/ $2011,664)$. For the individual woman not engaged in collective liberation, it will seem to her that she "needs to respect the male universe; if she contested it entirely, she would feel in danger, and without a roof over her head" (646). Speaking about the particular ways in which, and reasons why, people may resist destabilizing their current self-understandings can be interpreted as the concrete ways in which our existential flight from freedom and from the burden of our being or the ambiguity of human existence manifests itself.

43. Beauvoir comments that woman "projects her magic conception of reality ... [and in so doing] what she vainly tries to ward off in her long, despondent ruminations is the spectre of her own powerlessness" (Beauvoir 1949/2011, 655-66).

44. See note 21.

45. Indeed, this seems to be the narrative of many women who have been critical of the \#MeToo movement.

46. Levey makes a similar point (Levey 2005, 131).

\section{REFERENCES}

Bauer, Nancy. 2001. Simone de Beauvoir, philosophy, and feminism. New York: Columbia University Press.

- 2006. Beauvoir's Heideggerian ontology. In The philosophy of Simone de Beauvoir: critical essays, ed. Margaret Simons. Bloomington: Indiana University Press.

Beauvoir, Simone de. 1949/2011. The second sex. Trans. Constance Borde and Sheila Malovany-Chavallier. New York: Vintage.

Bigwood, Carol. 1993. Earth muse: Feminism, nature, and art. Philadelphia: Temple University Press.

Blattner, William. 2013. Authenticity and resoluteness. In The Cambridge companion to Heidegger's Being and Time, ed. Mark Wrathall. Cambridge, UK: Cambridge University Press.

Broeck, Sabine. 2011. Re-reading de Beauvoir "after race": Woman-as-slave revisited. International Journal of Francophone Studies 14 (1-2): 167-84.

Carman, Taylor. 2000. Must we be inauthentic? In Heidegger, authenticity, and modernity: Essays in honor of Hubert L. Dreyfus, volume 1, ed. Mark Wrathall and Jeff Malpas. Cambridge, Mass.: MIT Press.

Deneuve, Catherine. 2018a. Full translation of anti \#MeToo letter signed by Catherine Deneuve. Originally published in Le Monde, January 10. https:/www.worldcrunch.c om/opinion-analysis/full-translation-of-french-anti-metoo-manifesto-signed-by-ca therine-deneuve.

- 2018b. Catherine Deneuve: Rien dans le texte ne prétend que le harcèlement a du bon, sans quoi je ne l'aurais pas signé. Liberation, January 14. http://www.liber ation.fr/debats/2018/01/14/catherine-deneuve-rien-dans-le-texte-ne-pretend-que-leharcelement-a-du-bon-sans-quoi-je-ne-1-aurais_1622399. 
Dreyfus, Hubert. 1991. Being-in-the-world: A commentary on Heidegger's Being and Time, division 1. Cambridge, Mass.: MIT Press.

Freeman, Lauren. 2011. Reconsidering relational autonomy: A feminist approach to selfhood and the other in the thinking of Martin Heidegger. Inquiry 54 (4): 361-83.

Gines, Kathryn. 2014. Comparative and competing frameworks of oppression in Simone de Beauvoir's The Second Sex. Graduate Faculty Philosophy Journal 35 (1-2): 251-73.

Golob, Sacha. 2014. Heidegger on concepts, freedom and normativity. Cambridge, UK: Cambridge University Press.

Gothlin, Eva. 2003. Reading Simone de Beauvoir with Martin Heidegger. In The Cambridge companion to Simone de Beauvoir, ed. Claudia Card. Cambridge, UK: Cambridge University Press.

Graybeal, Jean. 1990. Language and "the feminine" in Nietzsche and Heidegger. Bloomington: Indiana University Press.

Guenther, Lisa. 2008. Being-from-others: Reading Heidegger after Cavarero. Hypatia 23 (1): 99-118.

Haslanger, Sally. 2004. Oppressions racial and other. In Racism in mind, ed. Michael P. Levine, and Tamas Pataki. Ithaca, N.Y.: Cornell University Press.

Heidegger, Martin. 1925/1985. History of the concept of time: Prolegomena. Trans. Theodore Kisiel. Bloomington: Indiana University Press.

- 1927/1962. Being and time. Trans. John Macquarrie and Edward Robinson. Southampton, UK: Basil Blackwell.

- 1928/1984. The metaphysical foundations of logic. Trans. Michael Heim. Bloomington: Indiana University Press.

Holland, Nancy. 2001. The universe is made of stories, not of atoms: Heidegger and the feminine they-self. In Feminist interpretations of Martin Heidegger, ed. Nancy Holland and Patricia Huntington. University Park: Pennsylvania State University Press.

Holland, Nancy, and Patricia Huntington, eds. 2001. Feminist interpretations of Martin Heidegger. University Park: Pennsylvania State University Press.

James, Susan. 2003. Complicity and slavery in The second sex. In The Cambridge companion to Simone de Beauvoir, ed. Claudia Card. Cambridge, UK: Cambridge University Press.

Knowles, Charlotte. 2017. Das Man and everydayness: A new interpretation. In From conventionalism to social authenticity: Heidegger's anyone and contemporary social theory, ed. Hans Bernhard Schmid and Gerhard Thonhauser. Cham, Switzerland: Springer.

Kruks, Sonia. 1987. Simone de Beauvoir and the limits of freedom. Social Text 17 (Autumn): 111-22.

- 2012. Simone de Beauvoir and the politics of ambiguity. Oxford: Oxford University Press.

Kutz, Christopher. 2000. Complicity: Ethics and law for a collective age. Cambridge, UK: Cambridge University Press.

Levey, Ann. 2005. Liberalism, adaptive preferences, and gender equality. Hypatia 20 (4): $127-43$.

Moi, Toril. 1999. What is a woman? And other essays. Oxford: Oxford University Press.

Mulhall, Stephen. 2005. Routledge philosophy guidebook to Heidegger and Being and Time. $2^{\text {nd }}$ ed. New York: Routledge. 
Sartre, Jean Paul. 1943/2003. Being and nothingness. Trans. Hazel Barnes. London: Routledge.

Schmid, Hans Bernhard. 2017. Authentic role play: A political solution to an existential paradox. In From conventionalism to social authenticity: Heidegger's anyone and contemporary social theory, ed. Hans Bernhard Schmid and Gerhard Thonhauser. Cham, Switzerland: Springer.

Wollstonecraft, Mary. 1792/1994. Political writings: A vindication of the rights of men, a vindication of the rights of woman, an historical and moral view of the origin and progress of the French revolution. Oxford: Oxford University Press.

Woolf, Virginia. 1928/2000. A room of one's own. London: Penguin.

Wyatt, Petronella. 2017. Today, BBC Radio 4, November. Transcribed in http://www. huffingtonpost.co.uk/entry/journalist-petronella-wyatt-flattered-groping-westminster_ uk_59fc6fbce4b0415a420b2348. 